\title{
Support for Improving the International Performance of Small and Medium-Sized Enterprises
}

\section{Silviya Georgieva*}

\begin{abstract}
The aim of this paper is to investigate the role of public support for the successful internationalization of small and medium-sized enterprises (SMEs) in Bulgaria. The focus is on the internationalization of this group of enterprises not only because of their great number, but also because of their contribution to Bulgarian economy. Out of the total number of SMEs, 500 companies are examined through a standardized questionnaire. These companies are from different economic sectors, and differ in terms of their size and type of ownership.

The results reveal that the public services most preferred by the surveyed companies for their successful internationalization are: providing information about foreign markets; encouraging participation in fairs and exhibitions; supporting the creation of contacts with potential partners. Often these companies receive needed services from local territorial administrations, and not from national ones. This suggests the need for a more active use of the potential of local administrations to support the SMEs internationalization. The results also show that the specific needs of a large group of
\end{abstract}

enterprises (the family-owned companies) are not well known yet.

Keywords: small and medium-sized enterprises, public support, internationalization, entrepreneurship

JEL code: L26, F23, L11

\section{Introduction}

Imost twenty years ago Europe Aacknowledged small and mediumsized enterprises (SMEs) as "the key to European competitiveness" (The European Charter for Small Enterprises, EC, 2000). "Small" enterprises are considered to be an important engine for achieving economic development and social inclusion through generating employment, innovations, added value and growth, as well as for creating more entrepreneurial citizens in Europe. For this reason, a number of leading authors examine the economic and social contribution of entrepreneurship and SMEs (Bridge, O'Neill, Martin, 1998, 2003, 2009; Casson, Yeung, Basu, Wadeson, 2006; Storey, Greene, 2010; Todorov, 2005, 2015; Simeonova-Ganeva, Vladimirov, Ganev etc., 2013; Vladimirov, 2014 , etc.). The recognised significance of SMEs determines the intense public interest in their development at various levels European institutions, national governments

Chief Assistant Professor, PhD, Institute of Entrepreneurship, University of National and World Economy, Bulgaria. 


\section{Articles}

and local authorities, as well as academia, experts, and media. All this has as a result led to the establishment of different policies for SMEs promotion.

The SMEs which successfully perform internationally are essential for the competitiveness of European countries. Especially for countries like Bulgaria with a limited domestic market, open economy and significant import, the international operations of companies are a source of sustainable growth and development.

Companies decide to internationalize their business for various reasons, such as: seeking profit and growth, international reputation, access to new customers and resources, and more (Vasileva, 2011; EC, 2014). Despite the proven benefits of internationalization, however, many SMEs remain oriented towards internal markets because of the various barriers they face in the process of internationalization (EU, 2015). This requires the implementation of proactive policies supporting the internationalization of SMEs.

Such policies are proposed because of the need to promote local firms under the intensive pressure of international competition (Seringhaus, Rosson, 1991). Research shows that there are many and varied measures to support the SMEs international business (Lederman, Olarreaga, Payton, 2010; Jalali, 2012; Fisher, Reuber, 2003; Catanzaro, Messeghem, Sammut, 2015; EC, Flash Eurobarometer 421-TNS Political \& Social, 2015). This in turn leads to attempts to classify these measures in order to evaluate more effectively their impact (Seringhaus and Rosson, 1991; Catanzaro, Messeghem, \& Sammut, 2015; EU, 2015, etc.). It has also been found that the growth of export support programmes in government budgets outstrips the growth of research in this area (Freixanet, 2012).
Despite the adopted policies in Bulgaria to support the SMEs internationalization, data indicate that SME exporters were barely $4.75 \%$ in 2016 and $4.9 \%$ in 2017 (Eurostat, 2019). This suggests that there might be some discrepancies between policies implemented and real needs of SMEs in respect to their internationalization. In this regard, improving the SMEs international performance requires solving a number of issues, such as: what specific support do companies need for successful internationalization; what type of services would help to increase their competitiveness; what institutions and organisations could provide the necessary assistance. The present article attempts to answer these research questions.

The paper is based on some of the data obtained from a standardized questionnaire sent out to 500 businesses across the country. The main goal is to analyze the role of public services offered to SMEs for their internationalization. The idea is to outline how SMEs evaluate different types of public support for internationalization, how many of them and what support they have benefited from, what assistance they feel they need to improve their international performance.

The results show that the most desired public services for successful internationalization of the surveyed companies are: providing information about foreign markets; encouraging participation in fairs and exhibitions; supporting the creation of contacts with potential partners, while financial support is placed on fourth place. It is revealed that the specific needs of a large group of enterprises (the family-owned ones) are not very popular yet. As SMEs often receive the necessary services from local territorial administrations, the need for more active use of their potential to support the internationalization process is disclosed. 


\section{Articles}

The article is organized in the following way. The first part presents the conceptual framework of the public support for the SMEs internationalization. The second part contains the methodology of the empirical survey, questionnaire and the characteristics of the sample companies. The third part shows the main results, conclusions and recommendations. The article ends by outlining the limitations and directions for future research.

\section{Conceptual framework of public support to SMEs internationalization}

\subsection{Necessity of SMEs internationalization}

A number of studies reveal a considerable contribution of SMEs to the economic and social development (Bridge, O'Neill, Martin, 1998, 2003, 2009; Casson, Yeung, Basu, Wadeson, 2006; Storey, Greene, 2010; Todorov, 2005, 2015; Simeonova-Ganeva, Vladimirov, Ganev etc., 2013; Vladimirov, 2014, etc.). The SMEs sector plays a sustainable dominant role in the European economy. For example, the SMEs are $99 \%$ of all companies in the EU, they provide two thirds of all jobs in the private sector and more than half of the total added value (EP, 2018). The data for Bulgaria are similar, where the non-financial SMEs are $99.8 \%$ out of the total 406310 enterprises (among which large companies are 744; 4601 are medium-sized; 25211 are small, and 375754 are micro enterprises) (NSI, 2018). The SMEs sector provides about $75 \%$ of the jobs and it generate around $65 \%$ of the added value (DIW Econ, 2018).

The SMEs development is strongly linked with the essential role of entrepreneurship, since the revival of the "European entrepreneurial spirit" is able to mobilize Europe for excellence (Action Plan, Entrepreneurship 2020, EESC, 2013). In countries like Bulgaria, which have experienced the transition
Support for Improving the International Performance of Small and Medium-Sized Enterprises

from centrally-planned to market economy, entrepreneurship contributes to the economic restructuring, middle class creation, and building a market oriented business culture based on a new value system (Todorov, 2015). In this respect, SMEs are essential to the economic growth, employment, regional and technological development. The inclusion of these businesses in internationalization is particularly important for countries like Bulgaria, which have limited resources and a smaller domestic market.

The SMEs are directly affected by processes of economic globalization, related to the decreasing trade and investment barriers, and to the expansion of large multinational companies. On the one hand, globalization opens up new opportunities for entering international markets, while on the other hand, it leads to the increased international competition. Today, the SMEs are facing this competition also in their internal markets, which is forcing them to internationalize if they are to survive (Knight, 2001).

Broadly speaking, internationalization encompasses not only import and export activities, but also the setting up of important business relations with foreign partners, inclusion in specialized international events, appointment of foreign managers as part of the company management, attraction of foreign capital, establishment of foreign representative offices, etc. (SimeonovaGaneva, Vladimirov, Ganev etc., 2013).

It is shown that successful performance on international markets brings a lot of benefits to businesses, including: opportunity for growth and higher profit, diversifying markets; opportunity to generate new ideas; access to needed resources; achieving economies of scale in delivery, manufacturing, marketing and research and development, etc. (Vasileva, 2011). Despite the undoubted benefits of participating in foreign markets, the dominant 


\section{Articles}

part of enterprises in the EU countries remains oriented towards the internal market. This could be explained by the fact that international activity requires overcoming various internal and external barriers. Internal barriers refer to problems associated with pricing, quality assurance, products' specifications, costs of internationalization, finding qualified personnel, language competences, etc. External barriers include difficulties in ensuring capital, access to information and sufficient public support; provision of all documents and resources to guarantee the transportation of the production; differences in the normative rules and business culture, tariffs, and other barriers (EC, 2014).

However, these barriers have different impact on SMEs in different countries insofar as they reflect the particularities of the national market and institutional environment. In this regard, there is insufficient research on the specific barriers that SMEs in Bulgaria are facing in their efforts to internationalize.

Some authors underline the increasing interest in the export potential of SMEs (Jatuliavičienè, Kučinskienè, 2012). Other researchers, however, observe that despite the growing number of export supporting programmes in the government budgets in the last two decades, this has not led to the respective increase in the research in this field (Freixanet, 2012).

The internationalization of SMEs varies widely with $13 \%$ contribution to Japan's exports (Boeva, 2014) to over $50 \%$ of total national exports in Italy, South Korea and China (Vasileva, 2011). However, Bulgaria is among the EU countries with the lowest shares of SMEs with experience in international business (about 15-16\% in 2016 and 2017 respectively). The SMEs importers from Bulgaria have a small share $(10.4 \%$ in 2016 and $10.9 \%$ in 2017), while SMEs exporters are barely $4.75 \%$ in 2016 and $4.9 \%$ in 2017 (Eurostat, 2019).

This situation emphasizes again the need for conducting in-depth research on the role of public support for the SMEs internationalization. This is particularly important in the context of Bulgarian economy, which accounts for a lower level of internationally active SMEs. It is necessary to understand how and through what services that institutions and organizations offer, the international activity of SMEs in Bulgaria can be increased.

\subsection{Promotion programmes for SMEs internationalization}

In general, the SMEs public assistance is provided according to normative acts, which regulate the types of support and specific measures to stimulate and finance their initiatives. Almost thirty years ago it was found out that companies look for export promotion programmes, while institutions offer such support. This could be explained by the growing importance of international trade and necessity to take part in it, as well as by the increased international competition and the need to strengthen national industrial sectors (Seringhaus, Rosson, 1991).

The need for more active international participation forces governments to implement programmes for encouraging export. Initially the aim of these programmes was to support local companies to conquer and preserve their positions in foreign markets, as well as to counteract the similar efforts to support export of other countries. In most of the cases the companies which already participate or intend to participate in international trade receive such support (Czinkota, Ronkainen, Moffet, 2011). Not surprisingly, Jindal and Gakhar (2015) find that there is a direct relationship between these promotional programmes and the company's growth and positive correlation 


\section{Articles}

between these programmes and the export competency of the enterprises.

The study of agencies promoting export shows that their activities include: creation of the image of the country (advertising, promotional events, advocacy); provision of export support services (training for export, technical support, building capacity, information about trade financing, logistics etc.); marketing services (trade fairs, exportimport missions etc.); market research and publications (general information about the sector at a company level, online information about export markets, e-bulletin, etc.) (Lederman, Olarreaga, Payton, 2006). All these activities reflect the attention and resources that governments devote to stimulate export (Jalali, 2012).

However, depending on the specific circumstances of each country, these activities should be prioritised in order to meet the specific needs of local SMEs. In addition, these activities must be tailored to the specific structure of the SME sector, which includes a number of different enterprises by sector, size, ownership and other characteristics.

Some authors suggest that support for export can be indirect through eliminating bureaucracy and encouraging innovations (Schmidt, Da Silva, 2015). Other researchers reveal that the SMEs promotion programmes include a wider range of activities, such as: disseminating information about foreign markets, supporting the establishment of contacts with brokers and agents, financial assistance in the form of trade credits or loans, special incentives such as support for initial costs of creating products for foreign markets (Fisher, Reuber, 2003).

There are data showing how government programmes supporting the SMEs internationalization are being addressed. In the OECD countries about $54 \%$ of the
Support for Improving the International Performance

of Small and Medium-Sized Enterprises

programmes are directed at overcoming market access barriers; $47 \%$ towards the use of financial instruments; $36 \%$ to support the firms' internal capabilities, while no more than $10 \%$ of government support aims to overcome difficulties arising from the business environment (Pietrasieński, Ślusarczyk, 2015). As it was said, there is insufficient research in Bulgaria on the specific barriers that the local SMEs face in the process of internationalization.

\subsection{Classifications of types of support for SMEs internationalization}

Different classifications of the support for export as a broadly accepted typology are suggested by Seringhaus and Rosson (1991), as researchers distinguish motivational, informational, operational assistance programmes. The European financial programmes have a direct impact on export because they make it possible for companies to enter foreign markets. On its part, the information and operational European programmes influence knowledge and networks of export start-ups, which impacts on their activity (Catanzaro, Messeghem, Sammut, 2015). There are also more detailed classifications, such as: financial assistance; training; advice; knowledge acquisition; market intelligence; information on market opportunities; bespoke information about specific markets; cross-border networking, general/multipurpose, and other (EC, 2015).

According to the survey conducted by the EC among SMEs, the largest share of respondents said that the elements of the financial programmes would help their internationalization: the provision of grants, subsidies or low-interest loans (30\%) and tax incentives (28\%). Another $27 \%$ are looking for support for finding business partners and networking; some $20 \%$ rely on the opportunity to participate in international trade fairs; the same amount need information about market 


\section{Articles}

opportunities; $19 \%$ require information about various rules and regulations; and $17 \%$ rely on advice or training. About a quarter of respondents (25\%), however, state that none of these measures would help their company to start doing business abroad (EC, 2015).

Alvarez (2004) considers that some forms of public support produce better results. While trade fairs and trade missions do not affect the probability for sustainable export, exporter committees have a significant and positive impact. In addition to export promotion programmes, process innovation also contributes positively to the SMEs export activity (Alvarez, 2004). However, other authors find a strong positive relationship between exports and visits to trade fairs and the establishment of offices abroad (Quaye, Sekyere, Acheampong, 2017). These differences in researchers' findings could be due to different institutional and market contexts, in which the surveyed SMEs operate.

The importance of trade shows for the SMEs internationalization studied through the prism of the network model reveals that these events surpass the marketing and information goals, and have a significant impact on the improvement of company's partnerships, which allows them to develop and enlarge internationally (Evers, Knight, 2008). Trade shows play an important role in building networking opportunities for all participants, thus facilitating internationalization. Shipley, Egan, and Wong (1993) identified 13 reasons for participation in trade fairs. Seven of them are closely related to sales, while six reasons - to non-sales activities, among which are: public relations, corporate reputation, and market research (cited by Da Silva, Friberg, 2017). This means that managers should reconsider the way in which they use trade shows, and pay more attention to their role in creation and development of international networks, which can enhance their competitive advantages (Evers, Knight, 2008). The use of trade shows and programmes, identifying representatives and distributors have a positive impact on the SMEs satisfaction with their export performance (Wilkinson, Brouthers 2006).

The great variety of public services used to stimulate SMEs internationalization can be summarized in the following groups, which are in line with the proposed classifications, and which take into account the national institutional and market context (Seringhaus and Rosson, 1991; Catanzaro, Messeghem, Sammut, 2015):

A. Information and training. This may include all activities related to the provision of key business information to stimulate entering in a specific foreign market or to expand the activity of an existing one. Providing knowledge in the appropriate forms and ways to the entrepreneurs/managers and to other key employees related to the successful performance in international markets.

B. Intermediary support. This group encompasses participation in various international events such as forums and fairs, where the company goods and services can be shown; relationships with different agents can be built; and networks with potential partners, clients and suppliers can be established. Administrative support for preparing specific documents - particularly for smaller companies, which have no adequate personnel capacity and frequently lack the relevant knowledge.

C. Financial support. This assistance has twofold directions: technological and marketing. The funds aimed at increasing the technological level of production, development and commercialization of innovations have a positive impact on firms' competitiveness. Providing means for marketing and advertising of the respective products or group of products makes them recognizable in the 


\section{Articles}

international market. Of particular importance are the resources directed at advertising the country as a whole.

It is essential for the success of SMEs' internationalization policies that the types of support are arranged in a way to meet the specific needs of local SMEs in each country. These activities should also be tailored to the specific barriers that SMEs face which differ from country to country. In addition, public support should take into account the structure of the SME sector, comprising different enterprises in terms of size, ownership, sector and other characteristics.

\subsection{Public support for SMEs internationalization in Bulgaria}

The provision of the above mentioned services is part of the policies of Bulgarian institutions and organizations to improve the SMEs international performance. At the same time, there is insufficient research on the degree of correspondence between the support offered and the specific needs of local SMEs.

\subsubsection{Basic documents and institutions for SMEs promotion in Bulgaria}

The support for SMEs development in Bulgaria includes a variety of measures and is regulated by documents such as: SMEs Law, National Strategy for the Promotion of SMEs 2014-2020, Innovation strategy for smart specialization of the Republic of Bulgaria 2014-2020, etc. The Ministry of Economy (ME) and the Bulgarian Small and Medium Enterprises Promotion Agency (BSMEPA) are the leading institutions aimed to support the business. One of the goals of the ME is to make Bulgaria an attractive long-term investment destination and an entry gate for goods and investment from East Asia and China to the EU (ME, 2018). For its part, BSMEPA applies an integrated approach to support exporters, encourage investment in
Support for Improving the International Performance

of Small and Medium-Sized Enterprises

export-oriented activities and improve the country's external positions (BSMEPA, 2019). Other institutions which provide support to the firms' international performance are: the Bulgarian Export Insurance Agency (BEIA) and the Investment Bulgaria Agency (IBA). BEIA provides insurance of export payments and foreign deals, and jointly with commercial banks has developed schemes which facilitate the financing of firms' international activities (BEIA, 2019). IBA provides detailed information about Bulgaria as a business destination and offers a wide range of services to foreign investors. (IBA, 2019).

Other organizations that provide services to the Bulgarian SMEs internationalization are: The Bulgarian Chamber of Commerce and Industry, The Bulgarian Industrial Association, the Association of Family Business in Bulgaria, The Bulgarian Association for Management Development and Entrepreneurship, and other industry organisations and unions.

\subsubsection{Types of support for SMEs internationalization in Bulgaria}

The programme support for the SMEs internationalization is provided mainly through the operational programmes (OP) such as: OP "Development of the Competitiveness of the Bulgarian Economy 2007 - 2013", OP "Innovation and Competitiveness 2014 2020".

For example, the OP "Competitiveness 2007-2013" has financed a project on "Promotion of the Internationalization of the Bulgarian Enterprises". Under this project various services were provided such as: creation of a national export internet portal and a maintenance of data base of enterprises with export potential; development of sector specific export strategies; organisation of promotional events; support for participation in international fairs, etc. (ISMM, 2019).

OP "Innovation and Competitiveness 2014-2020" provides services to promote 


\section{Articles}

export orientation of SMEs by: enhancing the entrepreneurial culture for organizing SMEs in clusters; providing information and advice on the European and third markets; organisation of contact information exchanges in Bulgaria, business forums in the country and abroad; supporting the participation of businesses in promotional missions abroad, as well as in national and international exhibitions (OPIC, 2014-2020). Within the framework of the same operational programmes, the project "Organizing Trade Missions and Forums for Bulgarian Manufacturers and Foreign Buyers" offers support for organizing individual and collective trade missions abroad; conducting business forums, B2B, and more (BSMEPA, 2019). The support for Bulgarian SMEs internationalization is also provided under OP "Initiative for SMEs" (OP "ISME", 2014-2020).

The existence of normative acts, institutions and organizations, funds and programmes supporting the internationalization of SMEs is indisputable. However, it is also essential to examine how SMEs evaluate the activities and assistance provided by the institutions, what support their companies have benefited from, and what assistance they feel they need in the future to improve their international performance.

\section{Methodology}

\subsection{Aim and research questions}

This article presents some of the results from an empirical research conducted under "Determinants and models of the competitive performance of small and medium enterprises in an international business environment" project ${ }^{1}$. The aim of the whole project is to enrich the understanding of the internationalization and sources of firms' competitive advantages, as well as the connection with their performance in foreign markets.

Specifically, this article analyses the services offered and the types of the assistance provided to SMEs in Bulgaria in the process of their internationalization. The key research questions aim to identify the support that companies have already received for their international activities, as well as the necessary and expected assistance in the future. The focus is on the respondents' evaluation of their experience with the institutions with which they work most often in respect to internationalization. It shows also how much the institutions are aware of the specific needs of family businesses as a significant part of the SMEs sector. The paper reveals the experience of entrepreneurs and managers in terms of the assistance provided by European, national or other programmes in support of their international activities.

\subsection{Questionnaire characteristics}

Through the structured questionnaire 500 companies with experience in internationalization are surveyed. The companies are from different sectors, and differ also in size and type of ownership. The questionnaire contains 69 questions, grouped into five modules. The first module aims to obtain both basic respondent and company information. The second one includes questions about firms' international activities and performance. The third module examines the entrepreneur, manager/successor. The fourth one contains questions about corporate governance and competitive performance. The fifth module is dedicated to networking and promoting the international activities of companies.

The article uses mainly the answers received within the last module. It includes a

${ }^{1}$ The project is funded by „Scientific Research” Fund, Ministry of Education and Science, Republic of Bulgaria, contract № дH05/15 15.12.2016 


\section{Articles}

total of thirteen questions. The main ones are: What support do Bulgarian institutions have to provide for the companies' international activities? Do the companies received assistance from European, national or other internationalization programmes? What kind of services, related to their internationalization the companies have used in the last five years? Which organizations provided these services? What type of services do the respondents think will be useful in the future? In respect to international activities which institutions do they most often need to work with? Do they consider that the Bulgarian institutions are well aware of the specific needs of the family companies? The survey was conducted over a period of four months in 2018.
Support for Improving the International Performance

of Small and Medium-Sized Enterprises

\subsection{Characteristics of the surveyed companies and entrepreneurs}

Entrepreneurs and managers are the people who are most actively involved in the international activity of the enterprises. The company founders play a key role, so it is important to outline their key characteristics. According to the respondents who answered these questions, the entrepreneurs are mostly men $(83 \%)$ and significantly fewer women $(17 \%)$. Around half of them are between 51 - 60 years of age, $36 \%$ are in the $41-50$ age group, $8 \%$ are over 60 years and the remaining $6 \%$ are between 31 - 40 years (Table 1).

Table 1. Characteristics of the surveyed entrepreneurs by gender and age (\%)

\begin{tabular}{|l|l|l|l|l|l|l|l|}
\hline & \multicolumn{2}{|l|}{ Gender } & \multicolumn{6}{l|}{ Age } \\
\cline { 2 - 8 } & Men & Women & $\mathbf{1 8 - 3 0}$ & $\mathbf{3 1 - 4 0}$ & $\mathbf{4 1 - 5 0}$ & $\mathbf{5 1 - 6 0}$ & Over 60 \\
\hline$\%$ & 83 & 17 & 0 & 6 & 36 & 50 & 8 \\
\hline
\end{tabular}

Source: own research

It is alarming that not one single young entrepreneur (under 30 years of age) is included in the sample. They may not have been sampled because they create and operate predominantly micro-enterprises. This fact, however, confirms a trend that was observed a few years ago - young entrepreneurs are no more than $5 \%$, those over 60 are nearly $15 \%$, and half of the business owners are over
46 years of age (BSMEPA, 2012). At that time, attention was paid to the potential risks to the sustainability of the sector, where in the short term (up to 5 years) about 15\% of SMEs had to transfer ownership to the next generation, and in the medium to long term $38 \%$ of SMEs would have to face this challenge (BSMEPA, 2012).

Table 2. Characteristics of the surveyed enterprises by size and field of activity (\%)

\begin{tabular}{|l|l|l|l|l|l|l|l|l|}
\hline & & Size & \multicolumn{5}{|l|}{ Field of operation } \\
\hline & Micro & Small & Medium & Big & Production & Services & Commerce & Other \\
\hline$\%$ & 1 & 73 & 23 & 3 & 48 & 29 & 19 & 4 \\
\hline
\end{tabular}

\section{Source: own research}

The micro firms in the sample amount to barely $1 \%$ despite the fact that they have the greatest share in the SMEs sector (over $92 \%$ of all non-financial enterprises in the country) (NSI, 2018) (Table 2). The research focus is on small and medium-sized enterprises due to their importance to the economy, including its internationalization. The micro companies, in particular, have limited representation in the sample because of the fewer possibilities 


\section{Articles}

for successful performance in international markets, while the big companies are excluded from the survey. According to the main activities, manufacturing companies have the largest share, followed by the firms operating in services and trade. The remaining enterprises are mainly from construction, research and development and others, which are not included in the above mentioned categories.

According to the respondents who answered the question about the legal form of the enterprise, a significant part said they are limited liability companies $-75 \%$ in total. The greater part of the surveyed firms are run solely by the entrepreneur (43\%); in $32 \%$ of the cases they have a limited liability partner/ partners; $9 \%$ of the companies are sole proprietorships; and half the latter figure are joint stock companies (5\%). The remaining part of the companies have a different organizational and legal form, such as: partnership, cooperatives etc. The greater share of companies are independent entities $(96 \%)$, i.e. they are not partners or affiliates under the Law on SMEs in Bulgaria.

Of the surveyed companies 267 (55.10\%) are importers, $188(38.80 \%)$ are regular exporters, and another $65(13.40 \%)$ are irregular, casual exporters. Out of the total,
59 companies (12.20\%) are involved in joint ventures; 57 (11.80\%) have commercial representation abroad, and 54 (11.10\%) participate in consortia. Other international activities are presented by fewer firms. The percentages exceed $100 \%$, as more than one answer is given.

\section{Results and discussion}

The literature review reveals a wide variety of services provided by different institutions and organisations to support the export activity of enterprises (Lederman, Olarreaga, Payton, 2010; Jalali, 2012; Fisher, Reuber, 2003; Catanzaro, Messeghem, Sammut, 2015; EC, Flash Eurobarometer 421-TNS Political \& Social, 2015). However, the question of how much and what type of support the SMEs in Bulgaria need to improve their international performance, is not sufficiently clear.

According to the empirical results, the surveyed SMEs indicated the top three of the necessary services that they expect to be guaranteed by the Bulgarian institutions:

- Providing information on foreign markets.

- Providing opportunities for company participation, including international fairs and exhibitions.

- Finding foreign partners. (Fig. 1).

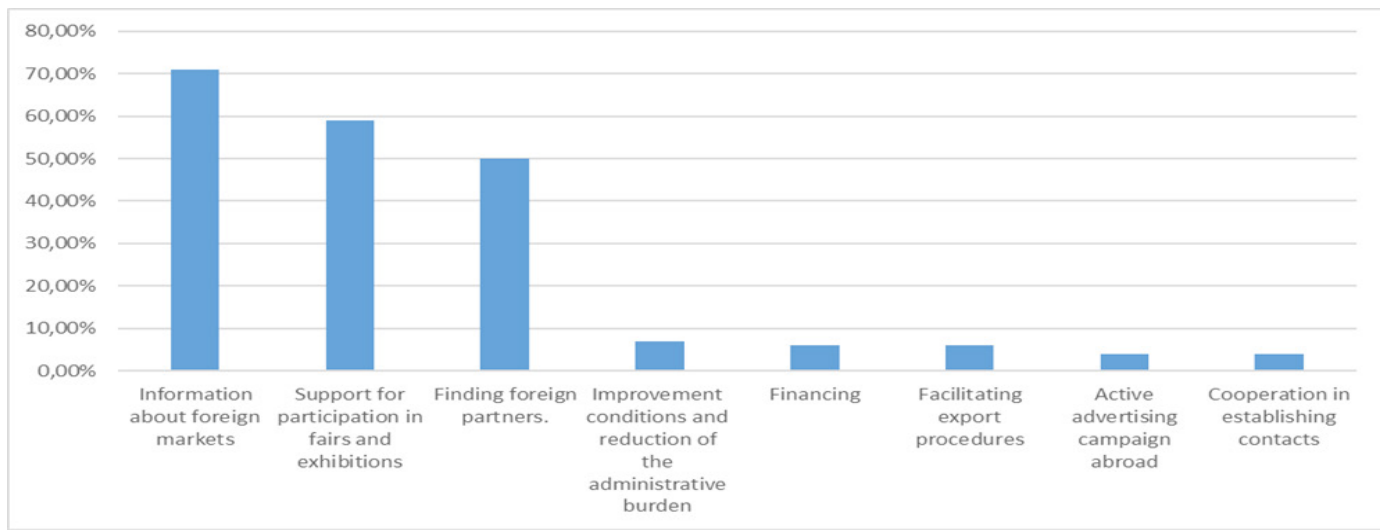

Figure 1. Distribution of necessary services to be assured by institutions for the international activity of SMEs in Bulgaria. (The percentages are more than $100 \%$, as more than one answer is given.) 


\section{Articles}

These three services categorically dominate over others, such as: providing additional financial resources for businesses; active advertising campaign abroad, etc. These types of services are also frequently discussed by different authors (Alvarez, 2004; Wilkinson, Brouthers 2006; Quaye, Sekyere, Acheampong, 2017), and by European institutions (EU, Flash Eurobarometer 421-TNS Political \& Social, 2015), but in different combinations. In the case of Bulgaria, financial support is ranked fifth in importance, which is substantially different from the preferences of the EU entrepreneurs as a whole. The EC (2015) survey shows that among the various possible forms of support, the most commonly selected measures by SMEs are financial assistance, tax incentives, support for finding business partners and networking, while less often are services like: opportunities to participate in international trade fairs, market information, and rules and regulations information.

The specific arrangement of necessary services for the SMEs internationalization in Bulgaria reflects the peculiarities of the business environment in the country. It is important to point out that necessary information apart from being timely should be sufficient in amount and of good quality. Participation in prestigious forums could promote company products/services and could make them better recognizable by potential foreign clients. Finding foreign partners makes it possible for companies in Bulgaria to join networks and/or various types of cooperation that have the potential to become strategic ones.

All the above mentioned services are also offered by the Bulgarian institutions and organisations (under OP "Development of the competitiveness of the Bulgarian economy 2007-2013" during the first programme period or projects under OP "Innovation and
Support for Improving the International Performance

of Small and Medium-Sized Enterprises

Competitiveness 2014-2020, OP "Initiative for SMEs") but without clear priorities. For example, an important factor in financial programmes is the amount of grants and the stage of company internationalization. If the grant is large enough, it may encourage already exporting companies to compete with each other in the international market, but there is little evidence that this will encourage domestic market oriented exporters to start exporting activities (Görg, Henry, Strobl, 2008). Given the persistently low share of exporters and importers among SMEs in Bulgaria, these programmes obviously do not help to increase internationally oriented companies, but rather contribute to the development of already established ones.

It is important to note that part of the respondents believe that the provision of a specific service is not necessary, rather the improvement of the conditions for the development of entrepreneurship in the country and the reduction of the administrative burden for business as a whole are of key importance. This vision is in line with the conclusions of Schmidt and Da Silva (2015) that the support can be indirect through reducing bureaucracy and promoting innovative policies.

Data show that about one fourth of the enterprises get support from European, national or other programmes related to the improvement of their international activity (Fig. 2).

At the same time, other data about Bulgaria show significant differences between the regions in the absorption of funds from the OP "Development of the competitiveness of the Bulgarian economy 2007-2013" by the companies. The leading role of the Southwestern region (with the capital city of Sofia) is established, where the beneficiaries have attracted several times more funds 


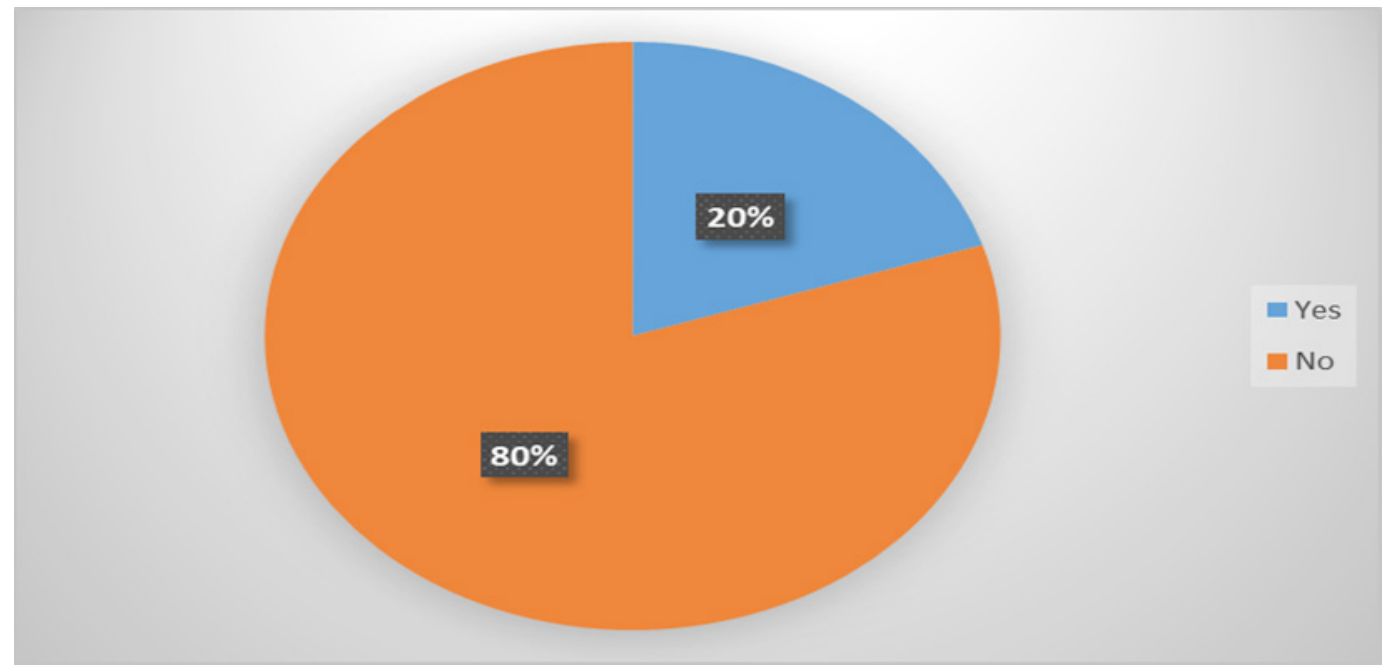

Figure 2. Support received from European, national and other programmes for the internationalization of SMEs in Bulgaria

compared to the Northwestern planning region - the least developed one (Georgieva, 2014).

Despite the opportunities for greater support for SMEs after the country's accession to the EU, assistance has reached only a fraction of companies. In many ways, companies registered in Sofia and some big regional centres have an advantage in accessing the services provided. This fact raises important questions regarding the access to information, communication between administrations and entrepreneurs, and the accessibility of aid to all enterprises throughout the country. The reported regional heterogeneity does not contribute to the development of entrepreneurship and SMEs in all areas of the country.

According to the respondents who answered the question about the services received for internationalization in the last five years, these services are provided via projects and programmes, financed mostly by the EU. The services with impact on the internationalization of their business are the following: consultancies; participation in conferences, business forums, and exhibitions; training; marketing and advertising. (Fig. 3)

It is worth noting that the sources of support for the assisted companies are very different in nature: institutions (Ministry of Finance, BSMEPA); various organizations (branch and consulting organizations, chambers of commerce and industry); other business organizations (partner companies, parent company). Few businesses have yet received a service from a scientific organization or university. These results indicate fragmentation and insufficient coordination in the provision of the services needed for SMEs internationalization, which makes it difficult for entrepreneurs to be aware of the opportunities they can benefit from. In addition, resources intended to support the internationalization of enterprises are being wasted.

At the same time, the coordination of all agents supporting internationalization is a prevention against duplication of programmes on the same topics and the loss of resources from this recurrence. It is also a mechanism to avoid "a jungle in the support" and to facilitate SMEs' access to relevant programmes (EC, Enterprise and Industry Directorate General, 2007). 


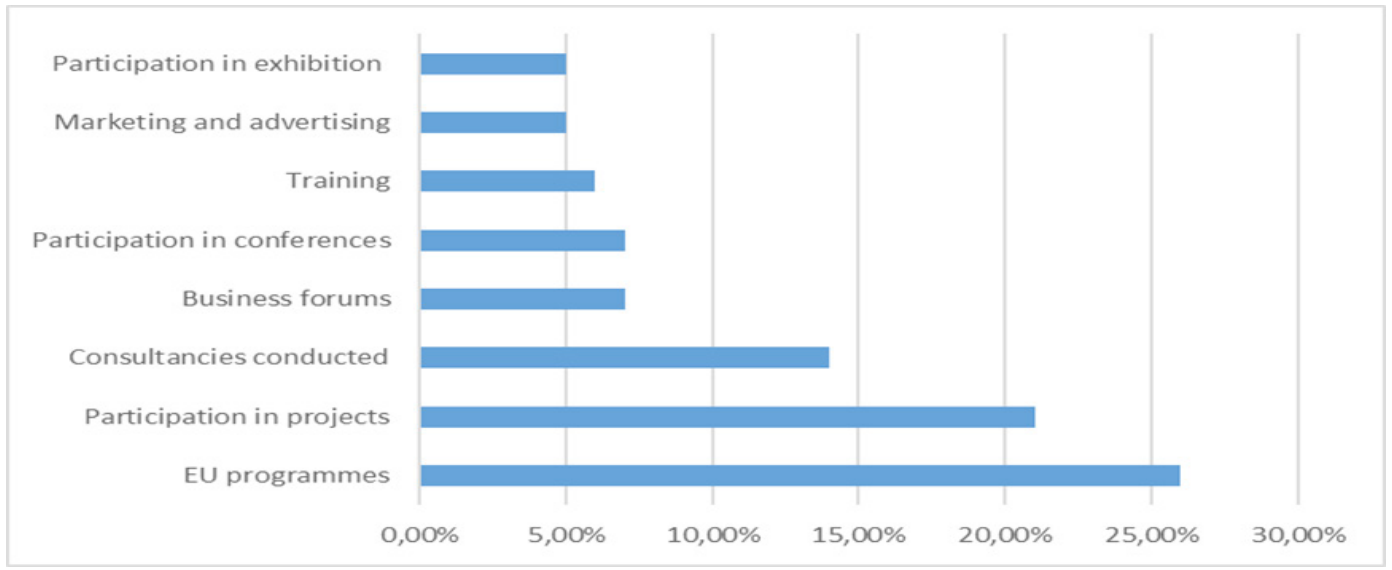

Figure 3. Services used by companies over the last 5 years, related to their internationalization

It is important to know how SMEs evaluate the knowledge of institutions about the needs and the specific characteristics of companies, especially the family-owned enterprises. The focus is on family-owned companies because of their share and contribution to the economy, which correlates with the priorities of some of the administrations and organisations, supporting the business. More than half of the respondents (52\%) state that Bulgarian institutions do not yet know well the characteristics of the family companies or their specific needs; $38 \%$ believe that administrations have identified part of the needs of these businesses; and only $10 \%$ believe that family businesses are well-studied and analysed by the institutions, which enables them to offer adequate support to their needs (Fig. 4).

At the same time, the survey data shows that more than half of the companies (57\%) are family-owned. According to respondents who answered the question, $77 \%$ declare their intention to transfer the ownership to the next generation, which can impact different key areas, including the internationalization activities. This process of inheriting ownership is related to the fact that $92 \%$ of the companies are still run by the entrepreneurs-founders.

According to the data, family businesses prevail among importers (32.60\%), and irregular exporters (7.80\%), while non-family

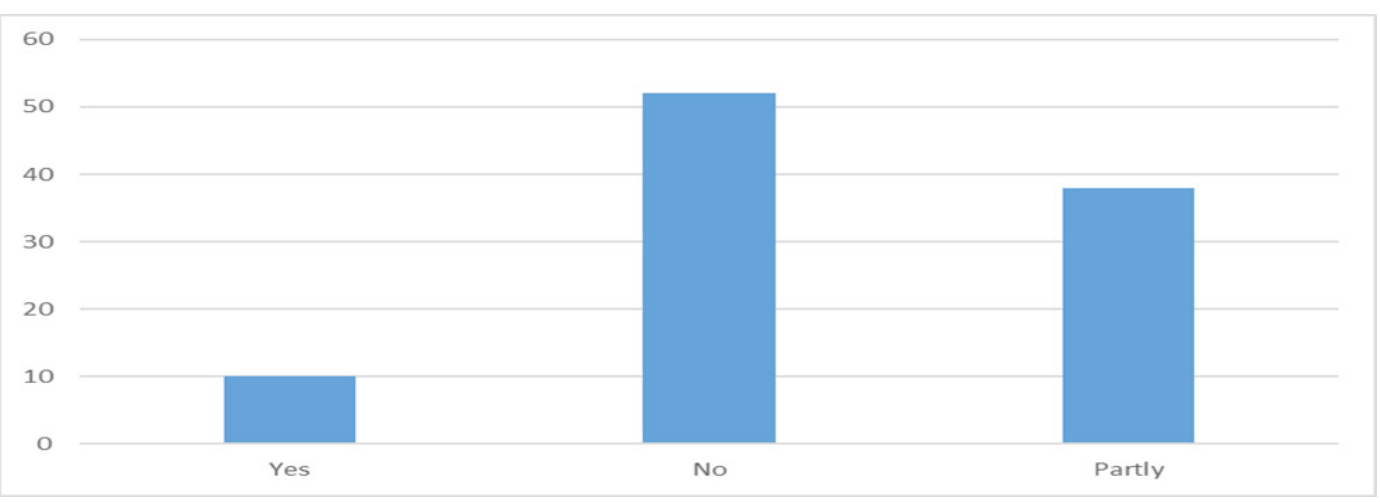

Figure 4. How well do institutions know the specific characteristics and needs of the family-owned companies? 


\section{Articles}

businesses have a greater share of regular exporters $(21.30 \%)$ and consortium companies (8.20\%) (Table 3).

Table 3. Prevailing types of international activities among family and non-family SMEs

\begin{tabular}{|l|l|l|l|l|l|l|l|l|l|}
\hline \multicolumn{2}{|c|}{} & Import & $\begin{array}{l}\text { Irregular, } \\
\text { casual } \\
\text { export }\end{array}$ & $\begin{array}{l}\text { Regular } \\
\text { export }\end{array}$ & $\begin{array}{l}\text { Joint } \\
\text { ventures }\end{array}$ & $\begin{array}{l}\text { Consortium } \\
\text { of companies }\end{array}$ & $\begin{array}{l}\text { Commercial } \\
\text { representation }\end{array}$ & Total \\
\hline \multirow{2}{*}{$\begin{array}{l}\text { Q 7. Does the } \\
\text { company identify as } \\
\text { a family business }\end{array}$} & \multirow{2}{*}{ Yes } & Count & 158 & 38 & 85 & 44 & 14 & 50 & 389 \\
\cline { 2 - 11 } & No of total & $32,60 \%$ & $7,80 \%$ & $17,50 \%$ & $9,10 \%$ & $2,90 \%$ & $10,30 \%$ & $80,20 \%$ \\
\hline & Count & 109 & 27 & 103 & 15 & 40 & 7 & 301 \\
\hline \multirow{2}{*}{$\begin{array}{l}\text { Total } \\
\%\end{array}$} & Count total & $22,50 \%$ & $5,60 \%$ & $21,30 \%$ & $3,10 \%$ & $8,20 \%$ & $1,50 \%$ & $62,20 \%$ \\
\hline
\end{tabular}

Percentages and totals are based on respondents. Only part of activities are shown.

a. Group (\% $>100 \%$ as respondents gave more than one answer)

At the same time, family businesses dominate other ways of internationalization, such as participation in joint ventures $(9.10 \%)$ and the presence of commercial representation (10.3\%). These differences outline the specifics of family businesses compared to non-family ones, which should be taken into account in support programmes for SME internationalization.

Important for the SMEs internationalization is the identification of administrative bodies, with which they most often work. The data show that the companies working mostly with regional authorities are more than two-thirds
$(78 \%)$, while those that use the services of central administrative bodies are 22\% (Fig. 5).

The decentralization of government and the existence of regional units outside the capital city saves time and money to companies located in the country. The business receives a considerable number of services from the municipal administration. This raises the questions, first, of the accessibility of the services provided to SMEs, including for their internationalization, throughout the country. Due to the fact that central institutions are situated mainly in Sofia and their branches in the big regional centres, some entrepreneurs located in smaller settlements probably

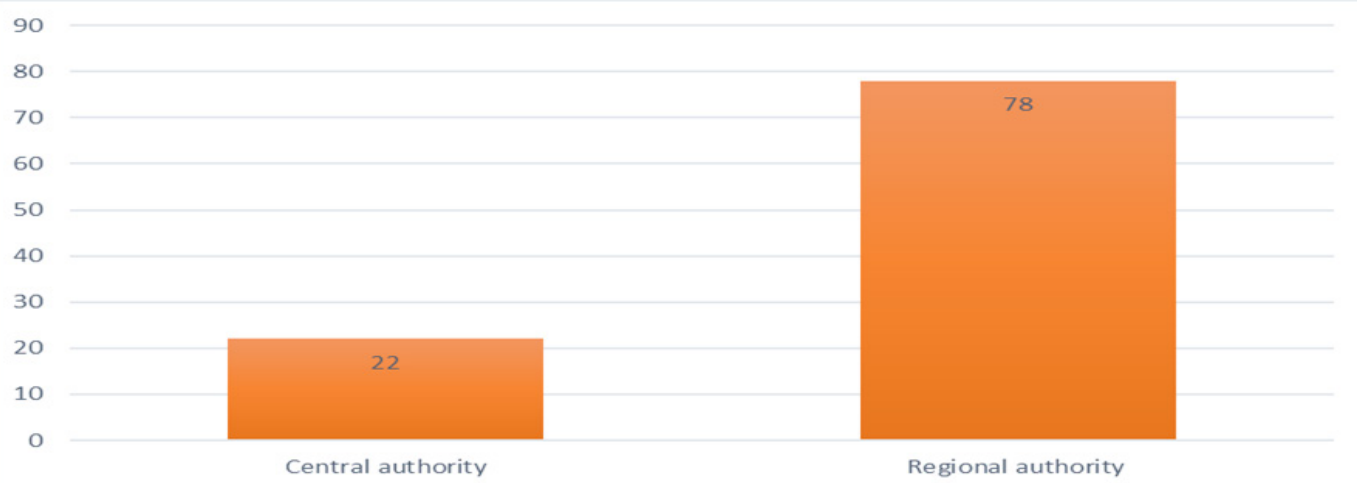

Figure 5. Share of institutions with which companies work more frequently in terms of their internationalization 


\section{Articles}

experience greater difficulties in receiving information about the support they need. This can further intensify the isolation of SMEs, which is actually their main problem (Todorov, 2015).

The second question concerns the potential role of the regional administrative authorities in promoting the SMEs internationalization. Municipal administrations, for example, are closer to citizens and businesses in the respective region and they could provide information and intermediary functions between the SMEs and the supporting institutions. Achieving this goal, however, requires to build capacity and very good communication infrastructure between
Support for Improving the International Performance of Small and Medium-Sized Enterprises

institutions, which often have different structure and specific working mechanisms. The EC also notes that as a whole the policies and programmes should be formulated at a national level, but the inclusion of regional and local stakeholders in their fulfilment will provide better and flexibility in the support adaptation (EC, Enterprise and Industry Directorate General, 2007).

Respondents expect that the institutions and organisations, promoting the business, will provide a wide range of services in the future. The results show a great dispersion of the support, desired by businesses, including the one for improving the positions in foreign markets (Fig. 6).

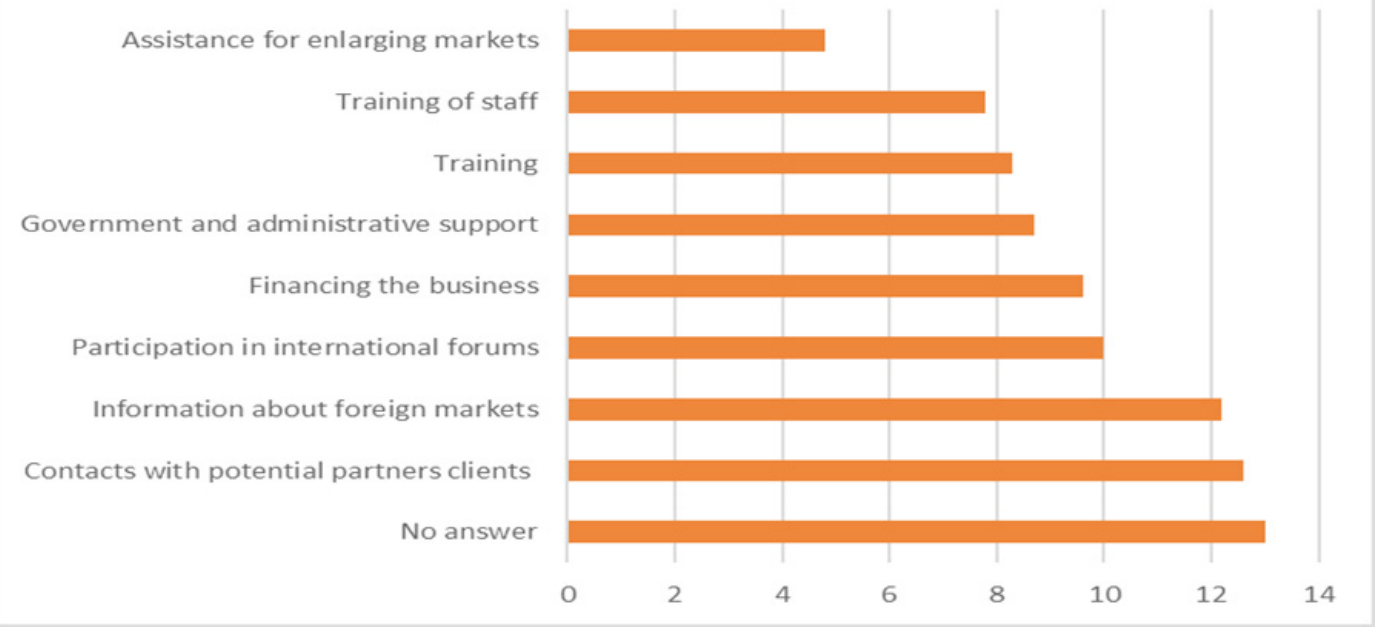

Figure 6. Distribution of most desired services by SMEs in the future (in \%)

Among the most anticipated forms of support are again: connecting with potential partners and clients, information on foreign markets, participation in international forums, followed by financial support placed in fourth place, trainings, market expansion, etc. Respondents also expressed their desire for: increasing the supply of electronic services, marketing and advertising, support for upgrading the technological level, assistance in obtaining certain certificates, development of innovations and/or transfer of innovations, etc. Almost $10 \%$ of the respondents expect the government to support the business purposefully and provide administrative assistance. These data indicate that SMEs rely on government policy for the improvement of their performance, and that there are innovative (electronic) services in this policy, which, however, seem to be neglected.

The specified differences in respect to necessary and expected services for the internationalization of SMEs in Bulgaria allow to make the following summaries. First, 


\section{Articles}

the most desired services by the SMEs in the country are: information about foreign markets, participation in fairs and exhibitions, establishing contact with potential partners and clients. Second, for their successful performance companies in Bulgaria rely heavily on the state policy and its role in creating a favourable business environment. Third, to increase the effectiveness of the support given to SMEs for their successful performance on international markets, it is necessary to know well the specifics of different groups of companies, including the family-owned ones, as the predominant group in the SMEs sector.

Based on the literature review and the results obtained from the empirical survey some recommendations can be made to institutions and organisations, encouraging the SMEs internationalization:

Recommendation 1: The great variety of services required and desired by SMEs in Bulgaria calls for better coordination between institutions and organisations in order to eliminate duplication of functions, the waste of resources and to offer more comprehensive support for the business. The survey revealed a large number of sources offering similar services to companies.

Recommendation 2: The establishment of the support complex for the successful presentation of SMEs on international markets should take into account the institutional and market context in which companies operate. The survey showed that financial aid was placed only in the fifth place in terms of importance, and on fourth place according to the expectations for future support. Moreover, a significant part of SMEs in Bulgaria rely on indirect business support by the State in creating a favourable business environment and reducing administrative burden.

Recommendation 3: Apart from the prominent role of the central institutions in improving the international activity of enterprises, the importance of territorial institutions is also accounted for. This suggests that local institutions can be involved more actively in the implementation of these policies.

Recommendation 4: The identified differences between family and non-family companies require that the specifics and needs of family firms as a dominant part of SMEs be better known. The support to family-owned enterprises that are prevailing among importers and casual exporters may increase the number of internationally oriented businesses, instead of helping only the already established exporters.

For their part, SMEs in Bulgaria can benefit from the variety of services offered by different sources through proactive behavior and participation in industry organizations and alliances for receiving timely information and creating networks.

\section{Conclusions}

The main purpose of this study was to analyze the role of public services offered for the internationalization of SMEs in Bulgaria. In this respect, answers to the following questions were sought: how SMEs in Bulgaria evaluate different types of public support for internationalization; what part of them and what support they have benefited from; which institutions are most often involved in internationalization; what support they feel they need to improve their international performance.

The results have shown that despite the available public support, most SMEs in Bulgaria have not been able to integrate into international markets even through the use of EU funds. This calls for the necessity to reorient respective policies and measures to fit better the needs of local SMEs. Not surprisingly, a significant share of respondents believe that 


\section{Articles}

the institutions are not yet familiar with the specifics of a large group of companies - the family ones.

There are also clear differences between preferences of SMEs in Bulgaria and those of the EU as a whole in respect to types of necessary and desired assistance from respective institutions. The most desired services by SMEs in Bulgaria are: providing information about the target market; identifying potential partners; providing opportunities for participation in international fairs and exhibitions, while financial aid occupied fifth place by importance, and fourth place by expectations. These services are also most expected by SMEs in the future, too, along with the pointed role of government in creating adequate regulations and control. The outlined differences can be understood by the specific national institutional and market context.

Limited resources require better coordination of assistance. Duplication of services from different institutions not only scatters resources, but makes it difficult for entrepreneurs to find the most appropriate support. In this context, regional administrations can play a significant role in providing more efficient assistance to the SMEs internationalization process.

The study has also some limitations. First, the surveyed companies are small and medium-sized firms with some experience in international business. Micro-enterprises have limited representation in the sample due to their smaller capacity to participate in international markets. Large companies are excluded from the survey. The survey focuses mainly on the institutional and programme support provided to enterprises in Bulgaria. The analysis is based on the evaluations of the respondents of the surveyed enterprises only, without a survey among the institutions and organizations, which are providing the respective support to the companies.
Support for Improving the International Performance

of Small and Medium-Sized Enterprises

Future research in this area may focus on exploring the support services for enterprises, grouped under different characteristics, such as: sector, export potential, settlement, innovation capacity, etc. In addition to already internationalized companies, the target of new studies may be enterprises with the potential for successful international performance. Another area of research is the evaluation of the efficiency and effectiveness of existing support for SMEs in the internationalization process. Such research can contribute to improving public support and achieving a higher share of internationalized SMEs.

\section{References}

Alvarez, R. (2004). Sources of export success in small- and medium-sized enterprises: the impact of public programs, International Business Review, Elsevier, vol. 13(3), 383-400

Boeva, B. (2014). Management in the conditions of internationalization and globalization, Publishing complex - UNWE, Sofia, (in Bulgarian)

Bridge, S., K. O’Neill, F. Martin (2009). Understanding Enterprise, Entrepreneurship and Small Business, Third Edition, London: Palgrave Macmillan Press.

Bulgarian Export Insurance Agency (2019). Available: http://baez.bg/, http://baez.bg/zanas, [Accessed 19 January 2019]

Bulgarian Small and Medium Enterprises Promotion Agency (BSMEPA) (2019). Available:https://www.sme. government. bg/,https://www.sme.government. bg/?page_id=35671, [Accessed 14 January 2019] (in Bulgarian)

Bulgarian Small and Medium Enterprises Promotion Agency (BSMEPA) (2019). Available: https://www.sme.government. bg/?page_id=86, [Accessed 14 January 2019] 


\section{Articles}

Bulgarian Small and Medium Enterprises Promotion Agency (BSMEPA) (2012). Analysis of the Situation and Factors for Development of SMEs in Bulgaria:2011-2012, Economic Recovery and Competitiveness, prepared by: Noema, Available: https://www. sme.government.bg/?p=10845, [Accessed 20 September 2018]

Casson, M., B. Yeung, A. Basu, N. Wadeson (Eds.) (2006). The Oxford Handbook of Entrepreneurship, Oxford University Press.

Catanzaro, A., K. Messeghem, S. Sammut (2015). Impact of export support: a conceptual model for export start-ups. Management international, 19(2), 226-245. https://doi.org/10.7202/1030397ar

Czinkota, M., I. Ronkainen, M. Moffet (2011). International business. Eighth Edition, John Wiley \& Sons Inc, ISBN-13 978-0-47053065-8

Da Silva, T., A. Friberg, (2017). Importance of Trade Shows for International Expansion: A Network Approach, Halmstad University, http://www.diva-portal.org/smash/get/ diva2:1078532/FULLTEXT01.pdf

DIW Econ (2018). SME Performance Review 2018, [Accessed 10 May 2019]

European Commission (2000). The European Charter for Small Enterprises (in Bulgarian)

European Commission (2014). Supporting the Internationalisation of SMEs, Guidebook Series How to support SME Policy from Structural Funds, Available:http://s3platform. jrc.ec.europa.eu/documents/20182/84453/ Supporting_Internat_SMEs.pdf/f36577c453fc-4f44-a02a-d8f5e295158f [Accessed 10 January 2019]

European Commission (2015). Flash Eurobarometer 421 - TNS Political \& Social, Internationalisation of small and mediumsized enterprises, the survey has been requested by the European Commission,
Directorate-General for Internal Market, Industry, Entrepreneurship and SMEs and co-ordinated by the Directorate-General for Communication.

European Commission, Enterprise and Industry Directorate-General (2007). Supporting the internationalisation of SMEs, Final Report of the Expert Group, Available: www.ec.europa.eu [Accessed 15 January 2019]

European Economic and Social Committee (2013). Action Plan „Entrepreneurship 2020, INT/679. Available: http://www.knsb-bg.org/ pdf/ $490 / P I a n_{-} z_{\text {a }}$ deystwie Predpriema4estwo2020.pdf, [Accessed 18 December 2018] (in Bulgarian)

European Parliament (2018). Fact Sheets on the European Union. Small and mediumsized enterprises, Available: http://www. europarl.europa.eu/factsheets/en/sheet/63/ small-and-medium-sized-enterprises, [Accessed 26 January 2019]

Eurostat (2019). Trade by NACE Rev. 2 activity and enterprise size class, [ext_ tec01], https://appsso.eurostat.ec. europa. eu/nui/submitViewTableAction.do [Accessed 02 August 2019]

Evers N., J. Knight, (2008), Role of international trade shows in small firm internationalization: a network perspective, International Marketing Review, Vol. 25 Issue: 5, 544-562, https://doi.org/10.1108/0265133 0810904080

Fischer, E., A. Reuber (2003). Targeting export support to SMEs: Owners' international experience as a segmentation basis. Small Business Economics, 20(1), 69-82

Freixanet, J. (2012). Export promotion programs: Their impact on countries' internationalization performance and competitiveness, International Business 


\section{Articles}

Review 21, 1065-1086, doi: 10.1016/j. ibusrev.2011.12.003

Georgieva, S., (2014). Programming support for companies in Bulgaria through EU Operational Programmes 2007-2013, Management and Sustainable Development 5 (in Bulgarian)

Görg, H., Henry, M., Strobl, E. (2008). Grant support and exporting activity, Review of economics and statistics, 90(1), 168-174. DOI: 10.2139/ssrn.950259

Information system for management and monitoring of EU funds in Bulgaria (2019). Available: http://umispublic.government.bg/ srchProjectlnfo.aspx? id=19315 [Accessed 14 January 2019] (in Bulgarian)

Information system for management and monitoring of EU funds in Bulgaria (2019). Available: http://umispublic.government.bg/ srchProjectInfo.aspx?id=19315, [Accessed 14 January 2019]

InvestBulgaria

Agency

(2019).

Available:http://www.investbg.government. bg/bg/pages/about-82.html, [Accessed 10 April 2019]

Jalali, S. (2012). The effect of export promotion programmes on export performance: Evidence from Iranian food manufacturers, International Journal of Business and Globalisation, Vol. 9, Issue 2, pp. 122-133, DOI:10.1504/ IJBG.2012.048955, https://www. researchgate.net/publication/264440618

Jatuliavičienè, G., M. Kučinskienè (2012). Export promotion changes of SME's for export expansion directions development in Lithuania, Regional formation and development studies, 1 (6), ISSN 2029-9370 Jindal G., K. Gakhar, (2015). Export Promotion Programs and Exporters Performance, Strategies and Competencies: A Review, International Journal of Research
Support for Improving the International Performance of Small and Medium-Sized Enterprises

in Management, Science \& Technology (E-ISSN: 2321-3264), Vol. 3, No. 4

Knight, G. A. (2001). Entrepreneurship and strategy in the international SME. Journal of International Management, 7, 155-171., PII: S1075-4253(01)00042-4

Lederman D., M. Olarreaga, L. Payton, (2006). Export Promotion Agencies: What Works and What Doesn't, World Bank Policy Research Working Paper 4044, November 2006.

Ministry of Economy (2015). Innovation Strategy for Smart Specialisation. The R of Bulgaria. Available: https://www. mi.government.bg/files/useruploads/files/ innovations/ris3_26.10.2015_en.pdf,

Ministry of Economy (2018). Operational Programme "Innovation and Competitiveness", Available: http://opic.bg/ opik/operativna-programa, (in Bulgarian) [Accessed 20 September 2018]

Ministry of Regional Development and Public Works (2013). North-western Regional Development Plan for the period 2014-2020, Available: http://www.strategy. bg, [Accessed 20 April 2018] (in Bulgarian) National statistical institute (2018). Number of enterprises. Available: http://www.nsi.bg, [Accessed 30 March 2019] (in Bulgarian)

Operational Program „Small and Medium Enterprises Initiative 2014-2020“, Available: https://www.eufunds.bg/ bg/opic/node/564, [Accessed 20 October 2018] (in Bulgarian) Operational Programme „Innovation and Competitiveness 2014-2020“, Available: www. eufunds.bg, [Accessed 20 October 2018] (in Bulgarian)

Pietrasieński P., B. Ślusarczyk (2015). Internationalization of small and medium enterprises - empirical research review on barriers to entry into foreign markets, Polish 
Journal of Management Studies, Vol.11 No1, 113-123

Quaye, D., K. Sekyere, G. Acheampong (2017). Export promotion programmes and export performance: a study of selected SMEs in the manufacturing sector of Ghana, Review of International Business and Strategy, https:// doi.org/10.1108/RIBS03-2017-0021

Schmidt, F., J. Da Silva, (2015). Export Assistance: A literature review and challenges for future research. Institute for Applied Economic Research (IPEA), http://repositorio.ipea.gov.br/ bitstream/11058/5141/1/Discussion Paper_191.pdf

Seringhaus, F.H., Ph. J. Rosson (1991). Export Promotion and Public Organizations: State-of-the-Art, Export Development and Promotion: The Role of Public Organizations, edited by F.H. Rolf Seringhaus, Philip J. Rosson, Springer Science \& Business Media

Shipley, D., Egan, C., Wong, K.S. (1993). "Dimensions of trade show exhibiting management", Journal of Marketing Management, Vol. 9, 55-63

Simeonova-Ganeva, R., Vladimirov, Zh., Ganev, K., Panayotova, N., Dimitrova, Ts., Davidkova. T., Yordanova, D., (2013). Study of Entrepreneurship and the Prospects for Innovations Development in SMEs (2012-2013), (BSMEPA), Available: https:// www.sme.government.bg/,https://www. sme.government.bg/en/uploads/ 2013/06/ SMEs_2013_en.pdf [Accessed 20 October 2018]

Storey, D. and F. Greene (2010). Small Business and Entrepreneurship, Harlow, United Kingdom: Pearson Education Limited.

Todorov, K. (2015). Business entrepreneurship, BAMDE, Sofa, (in Bulgarian)

Todorov, K. (2005). Foundation of Small Business, Second Revised and Expanded Edition, NEKST, Sofia, (in Bulgarian).

Vasileva, A. (2011). International Business, University publishing house Stopanstvo, Sofia, (in Bulgarian)

Vladimirov, Z. (2014). Theoretical Foundations of SMEs competitiveness in the context of Globalisation, ICSB World Conference, Ireland/Dublin.

Wilkinson, T., L. Brouthers (2006). Trade promotion and SME export performance, International Business Review, Volume 15, Issue $\quad 3, \quad 233-252$, doi:10.1016/j. ibusrev.2006.03.001 